\title{
EFFECTS OF EARLY WATER STRESS ON GRAPEVINE (VITIS VINIFERA L.) GROWING IN CV. SYRAH
}

\author{
KORKUTAL, I. ${ }^{1 *}-$ BAHAR, E. $^{1}-$ CARBONNEAU, A. ${ }^{2}$ \\ ${ }^{I}$ Department of Horticulture, Agricultural Faculty, Namik Kemal University \\ 59030 Tekirdag, Turkey \\ (phone: +90-282-250-2056) \\ ${ }^{2}$ Agro M, Viticulture-Oenologie (Emeritus), UMR \\ 2 place Viala, F-34060 Montpellier Cedex, France \\ *Corresponding author \\ e-mail: ikorkutal@nku.edu.tr; phone: +90-282-250-2059 \\ (Received $27^{\text {th }}$ Sep 2018; accepted $14^{\text {th }}$ Nov 2018)
}

\begin{abstract}
Water deficit is a major issue in grapevine production. The purpose of this research was to identify the effects of early water stress on the growing and yield of grapevine. The research was performed in SupAgro/INRA in Montpellier using the ECOTRON System, France. Syrah/SO4 graft combination was used as a plant material. 7 years old and potted grapevines were grown/kept in natural vineyard conditions. A completely randomized block design was used: $\mathrm{WS}_{0}$ (control) $0 ;-0.2 \mathrm{MPa}, \mathrm{WS}_{1}$ $0.2 ;-0.4 \mathrm{MPa}, \mathrm{WS}_{2}-0.4 ;-0.6 \mathrm{MPa}$, and $\mathrm{WS}_{3}-0.6 ;-0.8 \mathrm{MPa}$ respectively. The limitation of water was started the $15^{\text {th }}$ of May in the $17^{\text {th }}$ E-L stage and ended about the $15^{\text {th }}$ of June in the $27^{\text {th }}$ E-L stage. Analysis of variance was performed on the agronomic data using the MSTAT-C. Means were separated using the LSD test $(\mathrm{P}<0.01)$. It was determined that there was a reduction in vegetative growth. Also the predawn leaf water potential results showed differences between the irrigation levels. These results indicated that the lowest $\Psi_{\mathrm{pd}}$ in $\mathrm{WS}_{3}$ was $-0.80 \mathrm{MPa}$. There was an approximately $55 \mathrm{~cm}$ difference determined between the control and other groups in shoot lenghts. Besides that the average cluster weight was reduced by about $41 \%$ and the yield by about $28 \%$ under the early water deficit conditions.
\end{abstract}

Keywords: early water deficit, Vitis vinifera L., Syrah cv., vegetative development, yield

\section{Introduction}

Grapevine has been widely used as a model plant to study ecophysiological responses to water stress (Lovisolo et al., 2010). Grapevine growing is traditionally carried out in non-irrigated, extensive agricultural areas in semi-arid regions and dry lands. Abiotic stress, such as drought, reduces the rate of growing and photosynthesis of the grapevine thus limiting leaf functions and changing the source-sink balance. The results showed that berry composition was less sensitive to leaf: fruit ratio than to grapevine water status (Azevedo and Lea, 2011: Etchebarne et al., 2010).

The occurrence of water deficit is clearly important in order to state berry and wine composition. Also the irrigation provided certain wine sensory characteristics (Matthews et al., 1990). Though a late water deficit had no effect on ripening (Matthews and Anderson, 1988). In general, mild water deficits (-0.2 and -0.4 MPa) promoted wine quality in red varieties (Bravdo et al., 1985). Bahar et al. (2011) reported that sudden and extreme water stress results in smaller berries at harvest. On the other hand there is a reduction in the values of 100 berry weight and berry volume.

The effects of different levels of water deficit on growing Syrah berries were examined by Ojeda et al. (2002). Their results showed two types of berry responses to water deficit: an indirect and positive effect on the composition of phenolic compounds 
due to the limitation of berry size and a direct action on biosynthesis. The second response can have positive or negative effect the on composition of berries, type of phenolic compounds, application period, and water deficit severity. Otherwise De la Hera Orts et al. (2004) proved that the severe water stress, decreased vigor but also the content of acid and sugar due to photosynthetic activity may be compensated.

Water deficit had inhibition effects (Sadras and Moran, 2012) on reproductive and vegetative growth and changed the vine phenology (Coombe, 1992). Especially water deficit stress has a main effect on grapevine growth and berry development that in conclusion can impact wine quality (Tillet et al., 2011). The results of this study indicated the effects of early water stress levels on vegetative development in cv. Syrah.

\section{Materials and methods}

The test was conducted in the 2008 vegetation period by use of Supagro ECOTRON System in Montpellier. Seven years old Syrah / SO4 grafting combination was used as plant material which were planted in 72 L containers, because this cultivar is known as drought tolerant (Schultz, 1996). The test was designed according to a randomized complete block design into four parcels. It has 3 replications and 2 parcel based grapevines and 4 water stress levels $\left[\mathrm{WS}_{0}\left(4 \mathrm{~L} \mathrm{day}^{-1}\right), \mathrm{WS}_{1}\left(3 \mathrm{~L} \mathrm{day}^{-1}\right), \mathrm{WS}_{2}\left(2 \mathrm{~L} \mathrm{day}^{-1}\right)\right.$, $\mathrm{WS}_{3}\left(1 \mathrm{~L} \mathrm{day}^{-1}\right)$ ] (24 grapevines). All vines were equalized by 22 shoots and about 30 clusters. The research was carried out from the second week of May to the second week of June (17 th to $27^{\text {th }}$ ) (Eichorn and Lorenz, 1977). All plants were re-irrigated and fertilized $\left(6 \mathrm{~L} \mathrm{day}^{-1}\right)$ after early water stress period.

Stress groups were designed depending on predawn leaf water potential $\left(\Psi_{\mathrm{pd}}\right)$ according to Carbonneau (1998), Rogiers et al. (2014), Deloire and Rogiers (2014) $\mathrm{WS}_{0}$ (Control): 0; -0.2 MPa, $\mathrm{WS}_{1}$ : -0.2; -0.4 MPa; $\mathrm{WS}_{2}$ : -0.4; -0.6 MPa and $\mathrm{WS}_{3}:-0.6$; -0.8 MPa resp. Predawn leaf water potential $\left(\Psi_{\mathrm{pd}}\right)$ was measured at tertian days at 03:00 AM by using Scholander Pressure Chamber. Fully expanded leaves are measured $\left(\Psi_{\mathrm{pd}}\right)$ parcel based (Scholander et al., 1965). The measurement of predawn leaf water potential (PLWP; Iplwp), is performed before sunrise, when the stomata of the plant are closed and when the grapevine has been able to equilibrate its water potential with the wettest layer of the soil. PLWP is mainly used for research purposes only. Threshold values for PLWPplwp have been proposed by Carbonneau (1998), which makes it possible to evaluate the degree of water deficit experienced by the plant (Deloire and Rogiers, 2014). Vegetative parameters, such as shoot lengths $(\mathrm{cm})$ in 3 days intervals, shoot elongation rate $\left(\mathrm{cm}^{3}\right.$ days $\left.{ }^{-1}\right)$, also average cluster weights $(\mathrm{g})$ and yield $(\mathrm{kg}$ per vine) and water potential were measured.

Analysis of variance was performed on the agronomic data using the MSTAT-C statistical software. Means were separated using the LSD test $(\mathrm{P}<0.01)$.

\section{Results and discussion}

\section{Phenologic stages}

It was determined according to Eichhorn and Lorenz (1977), the phenologic stages and their dates are presented in Table 1. and also some climatic data in Figure 1. Ojeda et al. (1999) reported that the growing of grapevine in ECOTRON and in the vineyard is coherent. Nevertheless phenologic stages were not affected by the early water stress in Syrah cv. 
Table 1. The phenophases according to Eichhorn and Lorenz (1977) in cv. Syrah

\begin{tabular}{|c|c|c|}
\hline Stages E-L & Dates & Phenology \\
\hline 14 & 14 May & 6-7 leaves separated \\
\hline 15 & 15 May & 7-9 leaves separated \\
\hline 16 & 17 May & 10 leaves separated \\
\hline $17 *$ & 20 May & Inflorescence full developed \\
\hline 19 & 22 May & Beginning of flowering \\
\hline 20 & 23 May & $10 \%$ caps off \\
\hline 21 & 24 May & \multirow{3}{*}{$30 \%$ caps off } \\
\hline 21 & 28 May & \\
\hline 21 & 30 May & \\
\hline 23 & 31 May & \multirow{2}{*}{$50 \%$ caps off } \\
\hline 23 & 03 June & \\
\hline 25 & 04 June & $80 \%$ caps off \\
\hline 26 & 05 June & Cap-fall complete \\
\hline 26 & 06 June & Setting $(2 \mathrm{~mm})$ \\
\hline $27 * *$ & 09 June & Berries pepper corn size $(4 \mathrm{~mm})$ \\
\hline 29 & 13 June & \multirow{2}{*}{ Berries pea size ( $7 \mathrm{~mm})$} \\
\hline 31 & 16 June & \\
\hline 33 & 10 July & Berry touch \\
\hline 35 & 27 July & Veraison \\
\hline 38 & 11 September & Harvest \\
\hline
\end{tabular}

*Beginning of water stress; ** end of water stress

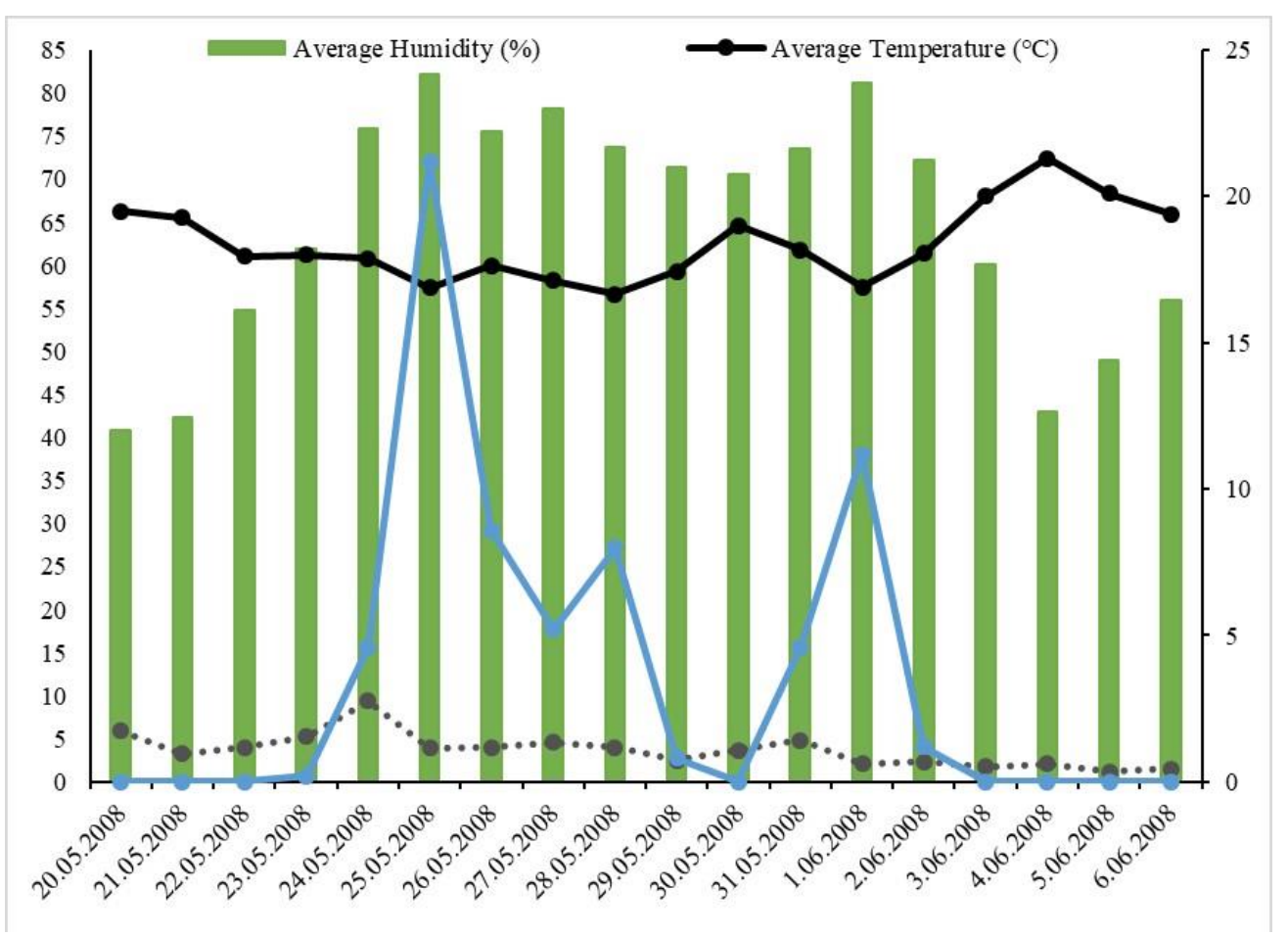

Figure 1. Some climatic data during early water stress 


\section{Predawn leaf water potential (MPa) $\left(\Psi_{p d}\right)$}

Vine water status was measured as $\Psi_{\mathrm{pd}}$ and has previously been reported (Bindon et al., 2008). $\Psi_{\mathrm{pd}}$ was approximately between 0 and $-0.30 \mathrm{MPa}$ in all treatments at the onset of the experiment. A statistically significant difference was found in $\Psi_{\mathrm{pd}}$ values in the stress groups. $\mathrm{WS}_{0}$ was a Control, it was full irrigated during the trial and the $\Psi_{\mathrm{pd}}$ values were between -0.21 to $-0.29 \mathrm{MPa}$. In $\mathrm{WS}_{1} \Psi_{\mathrm{pd}}$ values changed to -0.30 to $-0.53 \mathrm{MPa}$. In $\mathrm{WS}_{2}$ the highest $\Psi_{\mathrm{pd}}$ was $-0.33 \mathrm{MPa}$, and the lowest $\Psi_{\mathrm{pd}}$ was $-0.63 \mathrm{MPa}$. The lowest $\Psi_{\mathrm{pd}}$ in $\mathrm{WS}_{3}$ was -0.80 MPa. It was seen in Figure 2, that plants were irrigated in the 163 calendar days after bud break there was a linear decrease. Ojeda et al. (2001) notified that the water deficit in early period in cv. Syrah, on the $2^{\text {nd }}$ and on the $40^{\text {th }}$ days after anthesis, $\Psi$ indicated a difference of -0.5 and $-0.8 \mathrm{MPa}$, respectively these results supported our findings.

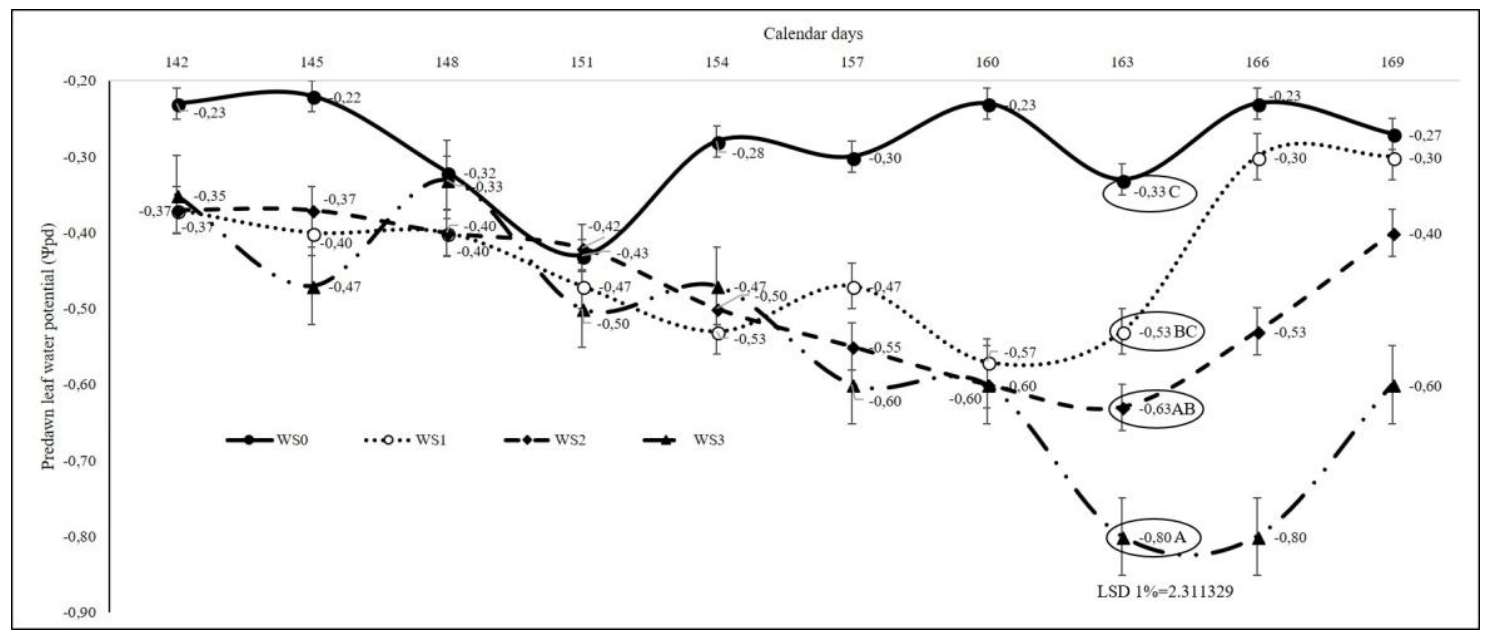

Figure 2. Changes in $\Psi_{p d}$ values during the experiment in Syrah cv.

\section{Vegetative growth}

Vegetative growth of Syrah cv. was photographed at different early water stress levels (Fig. 3). In semi-arid environments, early water deficit is therefore a usable tool for controlling vine vigour and canopy (Trigo-Córdoba et al., 2015).

Primary indicator of vine's water deficit is a reduction in leaf and shoot growth (Stevens et al., 1995). Yellow leaves were in plant basal, and also the poor berry set occurred according to the $\Psi_{\mathrm{pd}}$ values. Some leaves were detached from the grapevines. In berry set stage, some caps were attached the flowers. This samples were collected on date 18.06.2008 and even on date 28.06.2008. Also, the differences between treatments were detected in berry number per bunch (11.09.2008) same as Korkutal et al. (2011) previously have reported. This difference was seen at harvest when the cluster of Control compared to $\mathrm{WS}_{3}$ were photographed.

\section{Shoot length (cm)}

Just after the third measurement (28 May) there was about $15 \mathrm{~cm}$ variation in the control in the stress groups. In the last measurement this was approximately $55 \mathrm{~cm}$ 's (in the control and in all stress groups). These results are in compliance with the findings of Matthews et al. (1987) who noted an increase in shoot length with irrigation and Korkutal et al. (2011) who reported a $60 \mathrm{~cm}$ difference determined in Merlot cv. 


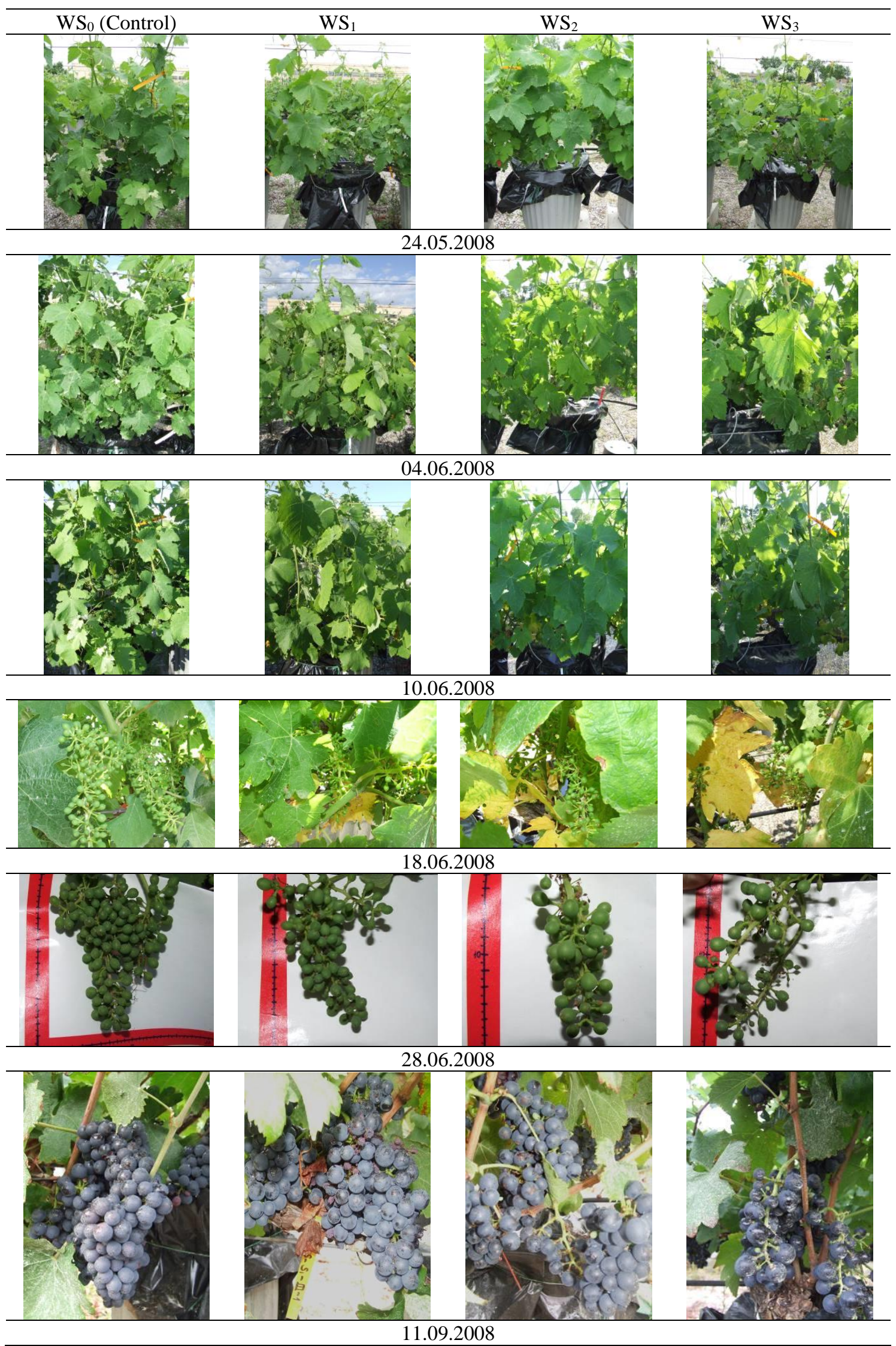

Figure 3. Vegetative growth of Syrah cv. under early water stress condition 
The data show that early water deficit has an effect on vegetative growth (Fig. 4). The vine water stress first noticeable symptom is a reduction in shoot growth (Williams, 2010; Keller, 2010). Shoot growth inhibition covers the reduction of internode extension, leaf expansion and tendril elongation (Hardie, 2000) and has been used as a sensitive indicator of grapevine water status (Pellegrino et al., 2005: Lebon et al., 2006). Vegetative growth was reduced because of the early water deficit, our results were in same direction with these researchers.

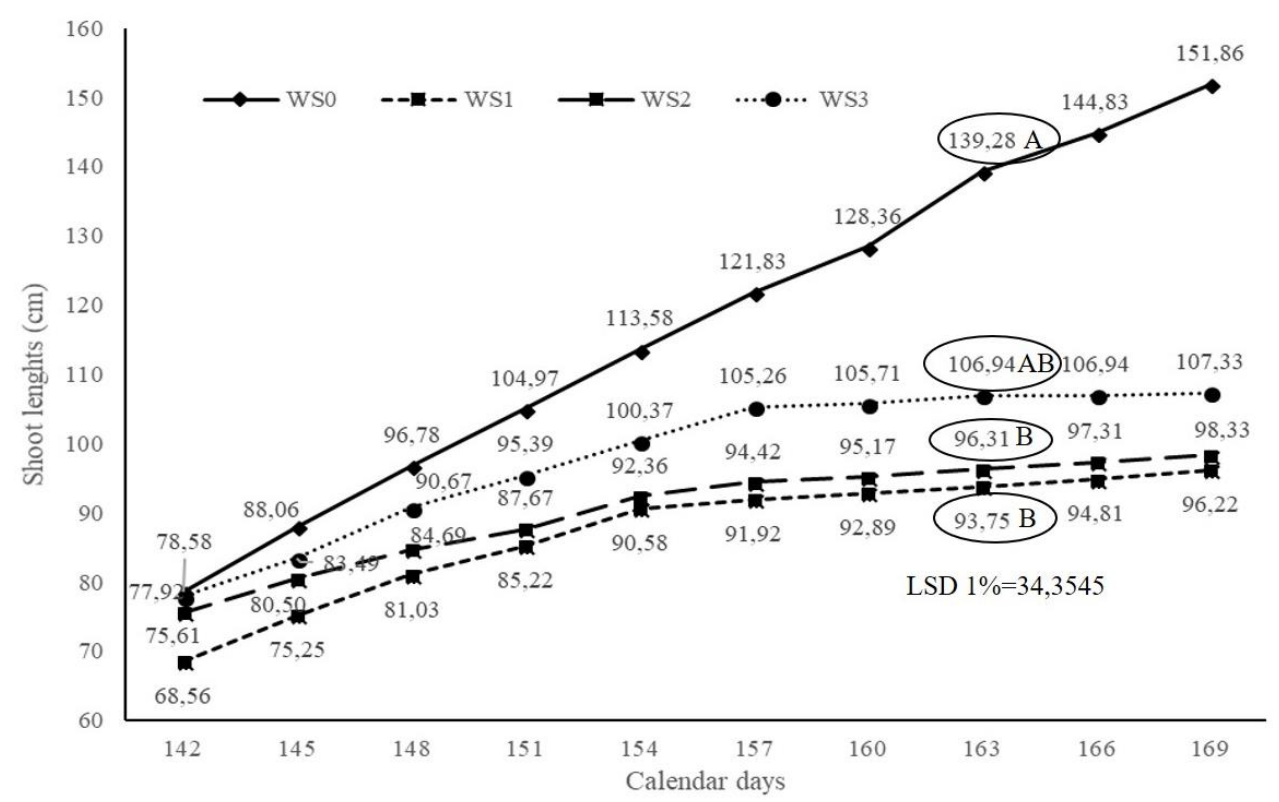

Figure 4. Shoot lengths according to the calendar days in Syrah cv.

\section{Shoot elongation rate (cm 3 days $^{-1}$ )}

Water limitation had a decreasing effect on shoot elongation rates (WS 3 ) (Fig. 5). Severe water deficit reduced shoot growth, changed grape berry composition and promoted ripening, but decrease of yield and berry mass due to excessive exposure was observed by Smart and Coombe (1983) likewise in our findings. When the mean of shoot elongation rates was examined in the stress groups, statistically significant differences $(\mathrm{P}<0.01)$ were determined between the control and other groups.

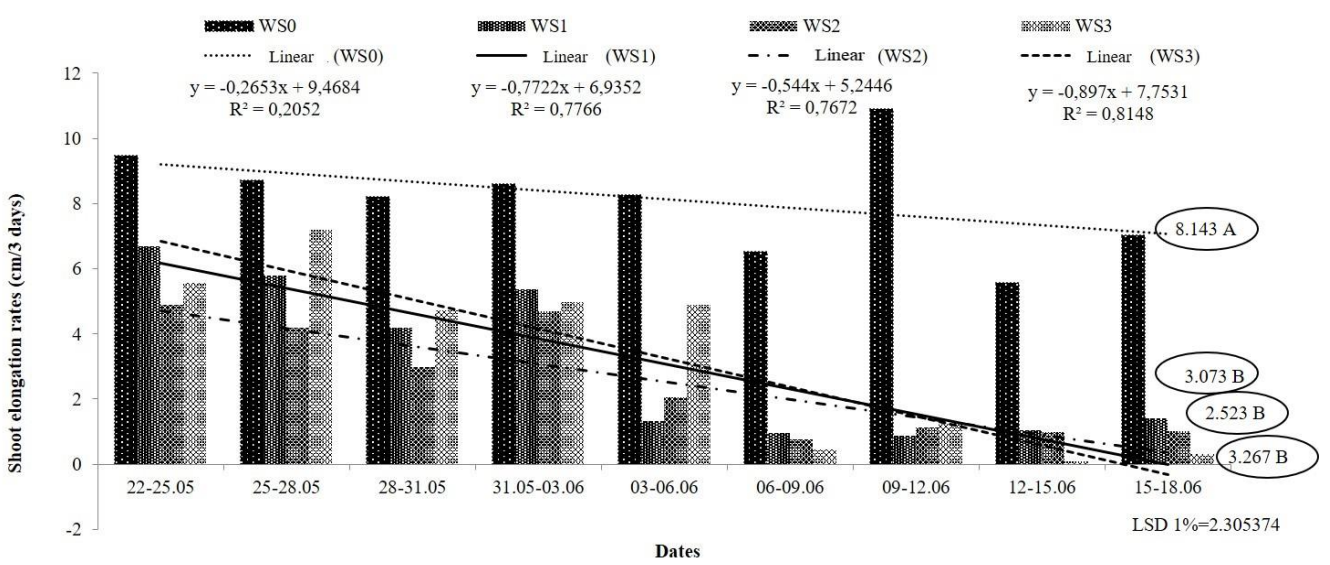

Figure 5. Shoot elongation rates in cv. Syrah 


\section{Average cluster weight (g)}

Differences in average cluster weight were found due to the stress levels but these were not statistically significant. Control grapevines had the highest average cluster weight $100.93 \mathrm{~g}$ and the lowest average cluster weight was measured in $\mathrm{WS}_{3}$ (59.88 g). Celik (2006) reported Syrah cv. average cluster weight as 200-250 g. Matthews and Anderson (1988) indicated that the inhibition of floral development may be a simultaneous consequence of low water status. Similar results were obtained in our experiment, average cluster weights decreased due to water scarcity. However, in our study because of the early water stress the clusters were smaller and lightweight like Xiao et al. (2018) and Buesa et al. (2017) reported the decrease in berry mass due to water deficit was remarkable (Table 2). Cluster weights decreased about $40.67 \%$ compared to control as a result of water stress.

Table 2. Average cluster weights and yield under early water stress

\begin{tabular}{c|c|c|c|c}
\hline & WS $\mathbf{0}$ (Control) & WS $_{\mathbf{1}}$ & $\mathbf{W S}_{\mathbf{2}}$ & $\mathbf{W S}_{\mathbf{3}}$ \\
\hline Average cluster weights (g) & 102.66 & 71.97 & 66.30 & 59.36 \\
$\mathrm{P}<0.01$ & $\mathrm{~ns}$ & $\mathrm{~ns}$ & $\mathrm{~ns}$ & $\mathrm{~ns}$ \\
\hline Yield (kg per vine) & 2.84 & 2.58 & 2.34 & 2.05 \\
$\mathrm{P}<0.01$ & $\mathrm{~ns}$ & $\mathrm{~ns}$ & $\mathrm{~ns}$ & $\mathrm{~ns}$ \\
\hline
\end{tabular}

ns: non significant

\section{Yield (kg per vine)}

In this research yield per grapevine was determined between $2.84 \mathrm{~kg}$ per vine and 2.05 $\mathrm{kg}$ per vine (Table 2). These results show that early water stress with increasing water stress levels had negative effect on yield (Smart and Coombe, 1983). Yield was reduced about $27.82 \%$ compared to control, under early water deficit but these values were not important statistically. This value was also supported by Shellie (2006) and Korkutal et al. (2011), 48\% and 50\% reduction in yield were determined under irrigation deficit. In addition to these Buesa et al. (2017) argued that in early deficit conditions, yield reduced by $25 \%$ compared with that of Control. It should not forgotten be that different deficit irrigation strategies are used to manage the yield (Keller et al., 2016).

Consequently, the period of the water deficit is crucial in specifying berry composition (Matthews et al., 1990). Reducing the irrigation water amount, with the potential to decrease shoot vigour with no yield loss is essential (Dry and Loveys, 1998). As expected, control irrigation resulted in higher yield than the others in our study and in the literature as well (Antolin et al., 2008). Cluster weights and yields were decreased about $40.67 \%$ and $27.82 \%$, respectively compared to control. These numeral differences in cluster weight and yield due to the water deficit can be explained by the development of small number but big size grape berries on the rachis.

\section{Conclusion}

To sum up our results:

- There was a reduction in vegetative growth.

- The $\Psi_{\mathrm{pd}}$ indicated the differences between the irrigation treatments. And the lowest $\Psi_{\mathrm{pd}}$ in $\mathrm{WS}_{3}$ was $-0.80 \mathrm{MPa}$. 
- In the last measurement of shoot lengths there was approximately a $55 \mathrm{~cm}$ difference between the control and other groups. Corresponding results in shoot elongation rates with water limitation were observed.

- Average cluster weight changed between 59.88 and 100.93 g. Cluster weight was reduced about $40.67 \%$ under early water deficit.

- Yield per grapevine was determined between $2.84 \mathrm{~kg}$ per vine and $2.05 \mathrm{~kg}$ per vine. It was proved that the early water deficit reduced $(27.82 \%)$ the yield.

Acknowledgements. Our sincere thanks for support belong to LEPSE, Director Thierry Simonneau, and the members of Plant Science Department from LEPSE. They also acknowledge Gäelle Rolland, Fida Khater (Ph.D. student) and Fatih Gunes Yener who is a Vinifera Euromaster student.

\section{REFERENCES}

[1] Antolin, M. C., Santesteban, H., Santa Maria, E., Aguirreolea, J., Sanchez-Diaz, M. (2008): Involvement of abscisic acid and polyamines in berry ripening of Vitis vinifera (L.) subjected to water deficit irrigation. - Australian Journal of Grape and Wine Research 14: 123-133. doi.org/10.1111/j.1755-0238.2008.00014.x.

[2] Azevedo, R. A., Lea, P. J. (2011): Research on abiotic and biotic stress - what next? Annals of Applied Biology 159: 317-319. doi.org/10.1111/j.1744-7348.2011.00500.x.

[3] Bahar, E., Carbonneau, A., Korkutal, I. (2011): The effect of extreme water stress on leaf drying limits and possibilities of recovering in three grapevine (Vitis vinifera L.) cultivars. - African Journal of Agricultural Research 6(5): 1151-1160. doi.org/10.5897/AJAR11.003.

[4] Bindon, K., Dry, P., Loveys, B. (2008): The interactive effect of pruning level and irrigation strategy on grape berry ripening and composition in Vitis vinifera L. cv. Shiraz. - South African Journal of Enology and Viticulture 29(2): 71-78. DOI: 10.21548/29-21439.

[5] Bravdo, B. A., Hepner, Y., Loinger, C., Tabacman, H. (1985): Effect of irrigation and crop level on growth, yield and wine quality of Cabernet Sauvignon. - American Journal of Enology and Viticulture 6: 132-139.

[6] Buesa, I., Pérez, D., Castel, J., Intrigliolo, D. S., Castel, J. R. (2017): Effect of deficit irrigation on vine performance and grape composition of Vitis vinifera L. cv. Muscat of Alexandria. - Australian Journal of Grape and Wine Research 23(2): 251-259. doi.org/10.1111/ajgw.12280.

[7] Carbonneau, A. (1998): Aspects qualitatifs. - Proceedings $17^{\text {th }}$ World Congress of Vine and Wine, Bratislava, pp. 258-276.

[8] Coombe, B. G. (1992): Grape Phenology. - In: Coombe, B. G., Dry, P. R. (eds). Viticulture, Vol: 1, Resources in Australia. Winetitles, Underdale, South Australia, pp. 139-153.

[9] Çelik, H. (2006): Grape Cultivar Catalog. - Sunfidan A. Ş. Mesleki Kitaplar Serisi: 3, Ankara.

[10] De La Hera Orts, M. L., Martinez-Cutillas, A., Lopez-Roca, J. M., Gomez-Plaza, E. (2004): Effects of moderate irrigation on vegetative growth and productive parameters of Monastrell vines grown in semiarid conditions. - Spanish Journal of Agricultural Research 2: 273-281. DOI: 10.5424/sjar/2004022-81.

[11] Deloire, A., Rogiers, S. (2014): Monitoring Vine Water Statues. Part 2: A Detailed Example Using the Pressure Chamber. - Grapevine Management Guide 2014-2015, NSW DPI, Orange, Australia, pp. 15-19. 
[12] Dry, P. R., Loveys, B. R. (1998): Factors influencing grapevine vigour and the potential for control with partial rootzone drying. - Australian Journal of Grape and Wine Research 4: 140-148. doi.org/10.1111/j.1755-0238.1998.tb00143.x.

[13] Eichhorn, K. W., Lorenz, D. H. (1977): Phaenologische Entwicklungsstadien der Rebe. Nachrichtenblatt des Deutschen Pflanzenschutzdienstes (Braunschweig) 29: 119-120.

[14] Etchebarne, F., Ojeda, H., Hunter, J. J. (2010): Leaf:fruit ratio and vine water status effects on Grenache Noir (Vitis vinifera L.) berry composition: water sugar, organic acids and cations. - South African Journal of Enology and Viticulture 31(2): 106-115. doi.org/10.21548/31-2-1407.

[15] Hardie, W. J. (2000): Grapevine biology and adaptation to viticulture. - Australian Journal of Grape and Wine Research 6: 74-81. doi.org/10.1111/j.17550238.2000.tb00165.x.

[16] Keller, M. (2010): The Science of Grapevines: Anatomy and Physiology ( $1^{\text {st }}$ ed.). Academic Press, Oxford.

[17] Keller, M., Romero, P., Gohil, H., Smithyman, R. P., Riley, W. R., Casassa, F., Harberson, J. F. (2016): Deficit irrigation alters grapevine growth, physiology, and fruit microclimate. - American Journal of Enology and Viticulture 67: 426-435. DOI: 10.5344/ajev.2016.16032.

[18] Korkutal, I., Bahar, E., Carbonneau, A. (2011): Growth and yield responses of cv. Merlot (Vitis vinifera L.) to early water stress. - African Journal of Agricultural Research 6(29): 6281-6288. DOI: 10.5897/AJAR11.1893.

[19] Lebon, E., Pellegrino, A., Louarn, G., Lecoeur, J. (2006): Branch development controls leaf area dynamics in grapevine (Vitis vinifera L.) growing in drying soil. - Annals of Botany 98: 175-185. doi: 10.1093/aob/mcl085.

[20] Lovisolo, C., Perrone, I., Carra, A., Ferrandino, A., Flexas, J., Medrano, H., Schubert, A. (2010): Drought-induced changes in development and function of grapevine (Vitis spp.) organs and their hydraulic and non-hydraulic interactions at the whole-plant level: a physiological and molecular update. - Functional Plant Biology 37: 98-116. DOI: 10.1071/FP09191.

[21] Matthews, M. A., Anderson, M. M. (1988): Fruit ripening in Vitis vinifera L: responses to seasonal water deficits. - American Journal of Enology and Viticulture 39(4): 313-320.

[22] Matthews, M. A., Anderson, M. W., Schultz, H. R. (1987): Phenologic and growth responses to early and late season water deficits in Cabernet franc. - Vitis 26: 147-160.

[23] Matthews, M. A., Ishii, R., Anderson, M. M., O’Mahony, M. (1990): Dependence of wine sensory attributes on vine water status. - Journal of the Science of Food and Agriculture 51: 321-335. doi.org/10.1002/jsfa.2740510305.

[24] Ojeda, H., Deloire, A., Carbonneau, A. (2001): Influence of water deficits on grape berry growth. - Vitis 40(3): 141-145.

[25] Ojeda, H., Deloire, A., Carbonneau, A., Georges, A., Romieu, C. (1999): Berry development of grapevines: Relations between the growth of berries and their DNA content indicate cell multiplication and enlargement. - Vitis 38(4): 145-150.

[26] Ojeda, H., Andary, C., Kraeva, E., Carbonneau, A., Deloire, A. (2002): Influence of preand post-véraison water deficit on synthesis and concentration of skin phenolic compounds during berry growth of Vitis vinifera L., cv. Shiraz. - American Journal of Enology and Viticulture 53: 261-267.

[27] Pellegrino, A., Lebon, E., Simmoneau, T., Wery, J. (2005): Towards a simple indicator of water stress in grapevine (Vitis vinifera L.) based on the differential sensitivities of vegetative growth components. - Australian Journal of Grape and Wine Research 11: 306-315. doi.org/10.1111/j.1755-0238.2005.tb00030.x.

[28] Rogiers, S., Deloire, A., Smith J., Tyerman, S. (2014): Monitoring Vine Water Status. Part 1: Some Physiological Principles. Grapevine Management Guide 2014-2015. NSW DPI, Orange, Australia, pp. 12-14. 
[29] Sadras, V. O., Moran, M. A. (2012): Elevated temperature decouples anthocyanins and sugars in berries of Shiraz and Cabernet Franc. - Australian Journal of Grape and Wine Research 18: 115-122. doi.org/10.1111/j.1755-0238.2012.00180.x.

[30] Scholander, R. R., Hammel, H. T., Bradstreet, E. D., Hemmiegsen, E. A. (1965): Sap pressure in vascular plants. - Science 148: 339-346. DOI: 10.1126/science.148.3668.339.

[31] Schultz, H. R. (1996): Water relations and photosynthetic responses of two grapevine cultivars of different geographical origin during water stress. - Acta Hort. 427: 251-266. DOI: 10.17660/ActaHortic.1996.427.30.

[32] Shellie, K. C. (2006): Vine and berry response of Merlot (Vitis vinifera L.) to differential water stress. - American Journal of Enology and Viticulture 57: 4.

[33] Smart, R. E., Coombe, B. G. (1983): Water Relations of Grapevines. - In: Kozlowski, T. T. (ed.). Water Deficits and Plant Growth, Vol. Vll, Additional Woody Crop Plants. Academic Press, New York. pp. 137-196.

[34] Stevens, R. M., Harvey, G., Aspinall, D. (1995): Grapevine growth of shoots and fruit linearly correlate with water stress indices based on root-weighted soil matric potential. Australian Journal of Grape and Wine Research 1: 58-66. doi.org/10.1111/j.17550238.1995.tb00079.x.

[35] Tillett, R. L., Ergül, A., Albion, R. L., Schlauch, K. A., Cramer, G. R., Cushman, J. C. (2011): Identification of tissue-specific, abiotic stress-responsive gene expression patterns in wine grape (Vitis vinifera L.) based on curation and mining of large-scale EST data sets. - BMC Plant Biology 11: 86. DOI: 10.1186/1471-2229-11-86.

[36] Trigo-Córdoba, E., Bouzas-Cid, Y., Orriols-Fernández, I., Díaz-Losada, E., MirásAvalos, J. M. (2015): Influence of cover crop treatments on the performance of a vineyard in a humid region. - Spanish Journal of Agricultural Research 13(4): 1-12. DOI: $10.5424 / \mathrm{sjar} / 2015134-8265$.

[37] Williams, L. E., Grimes, D. W., Phene, C. J. (2010): The effects of applied water at various fractions of measured evapotranspiration on reproductive growth and water productivity of Thompson Seedless grapevines. - Irrigation Science 28: 233-243. DOI 10.1007/s00271-009-0173-0.

[38] Xiao, Z., Liao, S., Rogiers, S. Y., Sadras, V. O., Tyerman, S. D. (2018): Effect of water stress and elevated temperature on hypoxia and cell death in the mesocarp of Shiraz berries. - Australian Journal of Grape and Wine Research 24(4): 487-497. doi.org/10.1111/ajgw.12363. 